\title{
Front Matter: Volume 7345
}

"Front Matter: Volume 7345," Proc. SPIE 7345, Multisensor, Multisource Information Fusion: Architectures, Algorithms, and Applications 2009, 734501 (13 April 2009); doi: 10.1117/12.829107 Event: SPIE Defense, Security, and Sensing, 2009, Orlando, Florida, United
States 


\section{PROCEEDINGS OF SPIE}

\section{Multisensor, Multisource Information Fusion: Architectures, Algorithms, and Applications 2009}

Belur V. Dasarathy

Editor

16-17 April 2009

Orlando, Florida, United States

Sponsored and Published by

SPIE

Volume 7345 
The papers included in this volume were part of the technical conference cited on the cover and title page. Papers were selected and subject to review by the editors and conference program committee. Some conference presentations may not be available for publication. The papers published in these proceedings reflect the work and thoughts of the authors and are published herein as submitted. The publisher is not responsible for the validity of the information or for any outcomes resulting from reliance thereon.

Please use the following format to cite material from this book:

Author(s), "Title of Paper," in Multisensor, Multisource Information Fusion: Architectures, Algorithms, and Applications 2009, edited by Belur V. Dasarathy, Proceedings of SPIE Vol. 7345 (SPIE, Bellingham, WA, 2009) Article CID Number.

ISSN 0277-786X

ISBN 9780819476111

Published by

SPIE

P.O. Box 10, Bellingham, Washington $98227-0010$ USA

Telephone +1 3606763290 (Pacific Time) · Fax +1 3606471445

SPIE.org

Copyright (C) 2009, Society of Photo-Optical Instrumentation Engineers

Copying of material in this book for internal or personal use, or for the internal or personal use of specific clients, beyond the fair use provisions granted by the U.S. Copyright Law is authorized by SPIE subject to payment of copying fees. The Transactional Reporting Service base fee for this volume is $\$ 18.00$ per article (or portion thereof), which should be paid directly to the Copyright Clearance Center (CCC), 222 Rosewood Drive, Danvers, MA 01923. Payment may also be made electronically through CCC Online at copyright.com. Other copying for republication, resale, advertising or promotion, or any form of systematic or multiple reproduction of any material in this book is prohibited except with permission in writing from the publisher. The CCC fee code is 0277-786X/09/\$18.00.

Printed in the United States of America.

Publication of record for individual papers is online in the SPIE Digital Library.

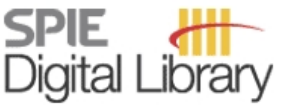

SPIEDigitalLibrary.org

Paper Numbering: Proceedings of SPIE follow an e-First publication model, with papers published first online and then in print and on CD-ROM. Papers are published as they are submitted and meet publication criteria. A unique, consistent, permanent citation identifier (CID) number is assigned to each article at the time of the first publication. Utilization of CIDs allows articles to be fully citable as soon they are published online, and connects the same identifier to all online, print, and electronic versions of the publication. SPIE uses a six-digit CID article numbering system in which:

- The first four digits correspond to the SPIE volume number.

- The last two digits indicate publication order within the volume using a Base 36 numbering system employing both numerals and letters. These two-number sets start with 00, 01, 02, 03, 04 , 05, 06, 07, 08, 09, OA, OB ... 0Z, followed by 10-1Z, 20-2Z, etc.

The CID number appears on each page of the manuscript. The complete citation is used on the first page, and an abbreviated version on subsequent pages. Numbers in the index correspond to the last two digits of the six-digit CID number. 


\section{Contents}

vii Conference Committee
ix Introduction

\section{SESSION 1 LOW-LEVEL FUSION}

734502 Evaluation of a color fused dual-band NVG [7345-02]

M. A. Hogervorst, A. Toet, TNO Human Factors (Netherlands)

734503 TRICLOBS portable triband color lowlight observation system [7345-03]

A. Toet, M. A. Hogervorst, TNO Human Factors (Netherlands)

734504 Enhancing image fusion performance and utility for defence and security applications [7345-04]

J. Sadler, M. I. Smith, Waterfall Solutions, Ltd. (United Kingdom)

734505 ACT-Vision: active collaborative tracking for multiple PTZ cameras [7345-05]

C. Broaddus, T. Germano, N. Vandervalk, A. Divakaran, S. Wu, H. Sawhney, Sarnoff Corp. (United States)

\section{SESSION 2 NETWORKS}

734506 Soft adaptive fusion of sensor energy for large-scale sensor networks (SAFE) [7345-07]

H. Rababaah, A. Shirkhodaie, Tennessee State Univ. (United States)

734507 Manned/Unmanned Common Architecture Program (MCAP) net centric flight tests [7345-08]

D. Johnson, U.S. Army Aviation Applied Technology Directorate (United States)

734508 A multi-layer network architecture for dynamic resource configuration and management of multiple mobile resources in maritime surveillance [7345-09]

R. Farahbod, U. Glässer, A. Khalili, Simon Fraser Univ. (Canada)

734509 Semantic enrichment of multi-intelligence data within a net-centric environment [7345-10] R. D. Hull, Modus Operandi (United States); L. Lashine, USA AMC (United States); D. Jenkins, Modus Operandi (United States)

\section{SESSION 3 FUSION SYSTEM ARCHITECTURES}

7345 OA Innovative system architecture for spatial volumetric acoustic seeing [7345-21]

E. Levin, A. V. Sergeyev, Michigan Technological Univ. (United States) 
7345 OB An integrated multi-source JDL high-level fusion architecture using recombinant cognition synthesis [7345-11]

M. A. Solano, Raytheon Intelligence and Information Systems (United States);

S. Ekwaro-Osire, Texas Tech Univ. (United States); M. M. Tanik, The Univ. of Alabama at Birmingham (United States)

7345 OC Information fusion across expert groups with dependent and independent components [7345-12]

V. M. Vergara, S. Xia, T. P. Caudell, The Univ. of New Mexico (United States)

7345 OD Data Fusion Engine (DFE) for the Force Protection Joint Experiment (FPJE) [7345-13]

C. M. Barngrover, R. T. Laird, T. A. Kramer, J. R. Cruickshanks, S. H. Cutler, Space and Naval Warfare Systems Ctr., San Diego (United States)

7345 OE FuzzyFusion: an application architecture for multisource information fusion [7345-14] K. L. Fox, R. R. Henning, Harris Corp. (United States)

\section{SESSION 4 APPLICATIONS I}

7345 OF Explosive detection in the presence of clutter by processing Raman spectra with a kernel adatron [7345-15]

A. E. Stevens, P. T. Rourke, E. A. Rietman, Physical Sciences, Inc. (United States)

7345 OG Sharing and fusing landmark information in a team of autonomous robots [7345-17]

D. M. Lyons, Fordham Univ. (United States)

$7345 \mathrm{OH} \quad$ Energy Logic (EL): a novel fusion engine of multi-modality multi-agent data/information fusion for intelligent surveillance systems [7345-19]

H. Rababaah, A. Shirkhodaie, Tennessee State Univ. (United States)

\section{SESSION $5 \quad$ APPLICATIONS II}

7345 Ol Force Protection Joint Experiment (FPJE) Battlefield Anti-Intrusion System (BAIS) sensors data analysis and filtering metrics [7345-20]

C. M. Barngrover, R. T. Laird, T. A. Kramer, J. R. Cruickshanks, S. H. Cutler, Space and Naval Warfare Systems Ctr., San Diego (United States)

7345 0J Biologically-inspired robust and adaptive multi-sensor fusion and active control [7345-22] D. Khosla, P. A. Dow, D. J. Huber, HRL Labs., LLC (United States)

7345 OK Information abstraction for enhanced image fusion based surveillance systems [7345-24] S. F. Page, M. I. Smith, D. Hickman, Waterfall Solutions, Ltd. (United Kingdom); P. K. Kimber, SELEX Galileo, Ltd. (United Kingdom)

\section{SESSION $6 \quad$ MISCELLANEOUS ISSUES AND APPROACHES}

$7345 \mathrm{OL} \quad$ Target tracking for randomly varying number of targets and sensors using random finite set theory [7345-25]

A. M. Ali, R. E. Hudson, K. Yao, Univ. of California, Los Angeles (United States) 
$73450 \mathrm{M}$ Field-based data collection techniques for the evaluation of information fusion systems [7345-27]

B. Antonishek, B. A. Weiss, C. Schlenoff, National Institute of Standards and Technology (United States)

7345 ON A local approach for focussed Bayesian fusion [7345-28]

J. Sander, Univ. Karlsruhe (Germany); M. Heizmann, Fraunhofer-Institut für Informations-und Datenverarbeitung IITB (Germany); I. Goussev, Univ. Karlsruhe (Germany); J. Beyerer, Univ. Karlsruhe (Germany) and Fraunhofer-Institut für Informations-und Datenverarbeitung IITB (Germany)

734500 3D hierarchical spatial representation and memory of multimodal sensory data [7345-29] D. Khosla, P. A. Dow, D. J. Huber, HRL Labs., LLC (United States)

7345 OP Multisensor information compression and reconstruction [7345-26]

B. Du, L. Liu, J. Zhang, Beihang Univ. (China)

Author Index 
Downloaded From: https://www.spiedigitallibrary.org/conference-proceedings-of-spie on 26 Apr 2023

Terms of Use: https://www.spiedigitallibrary.org/terms-of-use 


\title{
Conference Committee
}

\author{
Symposium Chair \\ Ray O. Johnson, Lockheed Martin Corporation (United States) \\ Symposium Cochair
}

Michael T. Eismann, Air Force Research Laboratory (United States)

Conference Chair

Belur V. Dasarathy, Consultant, Information Fusion Technologies

(United States)

Program Committee

Sheela V. Belur, The Van Dyke Technology Group, Inc. (United States)

Jerome J. Braun, MIT Lincoln Laboratory (United States)

Michael Heizmann, Fraunhofer-Institut für Informations-und Datenverarbeitung (Germany)

Charles F. Hester, OPTS, Inc. (United States)

Mieczyslaw M. Kokar, Northeastern University (United States)

Damian M. Lyons, Fordham University (United States)

Firooz A. Sadjadi, Lockheed Martin Corporation (United States)

S. Richard F. Sims, U.S. Army Aviation and Missile Research, Development and Engineering Center (United States)

Pierre Valin, Defence Research and Development Canada Valcartier (Canada)

Shanchieh Jay Yang, Rochester Institute of Technology (United States)

\section{Session Chairs}

1 Low-Level Fusion

Jerome J. Braun, MIT Lincoln Laboratory (United States)

Belur V. Dasarathy, Consultant, Information Fusion Technologies

(United States)

2 Networks

Damian M. Lyons, Fordham University (United States)

Charles F. Hester, OPTS, Inc. (United States) 
3 Fusion System Architectures

Charles F. Hester, OPTS, Inc. (United States)

Michael Heizmann, Fraunhofer-Institut für Informations-und

Datenverarbeitung (Germany)

4 Applications I

Jerome J. Braun, MIT Lincoln Laboratory (United States)

Sheela V. Belur, The Van Dyke Technology Group, Inc. (United States)

5 Applications II

Michael Heizmann, Fraunhofer-Institut für Informations-und

Datenverarbeitung (Germany)

Shanchieh Jay Yang, Rochester Institute of Technology (United States)

$6 \quad$ Miscellaneous Issues and Approaches

Pierre Valin, Defence Research and Development Canada Valcartier (Canada)

Damian M. Lyons, Fordham University (United States) 


\section{Introduction}

This is our 13th consecutive offering in the ongoing series on multisensor, multisource information fusion with nearly 430 papers published thus far. As the title indicates, the scope of the conference includes fusion of information not only from multiple traditional sensors but also from other nontraditional data sources, and are spread across the three key facets of developments in the field, namely, architectures, algorithms, and applications. While the conference title remains constant, the sessions and their titles are redefined each year to better reflect the changing contents, which are driven by the evolving research and development activities in the community. Accordingly, this year, the presentations have been grouped into the following six sessions:

- Low-Level Fusion

- Networks

- Fusion System Architectures

- Applications I and II

- Miscellaneous Issues and Approaches

Following the traditions of the years past, and in contrast to the general policy of post-conference publication of the proceedings at most SPIE sister conferences, we along with the SPIE staff have worked hard to once again provide the printed proceedings on-site at the conference. This not only serves the purpose of rapid dissemination in print form of the most recent developments in this area but also helps in better understanding and appreciation of the oral presentations by the audience. Incidentally, it also complements the prime archival journal in this field, Information Fusion, which because of its dependence on formal and rigorous peer reviews is a more drawn-out process along the timeline. Another benefit, of this procedure of making the proceedings available on-site at the time of the conference, is that it enables better quality control over the presentations by limiting the program to those that have the full manuscript ready and thereby ensuring a more mature presentation. Occasionally, this process results in a culling of the initial submissions. While this decrease represents the downside of the process, we remain confident of its upside, namely, better quality control.

The international character of this conference is once again reflected, not only in the program committee, but also in the contents of the proceedings, which includes 24 papers from 6 countries (representing a significant reduction as compared to last year, perhaps a measure of the global economic downturn) Canada, China, Germany, Netherlands, United Kingdom, and, of course the United States. We plan to continue this series in the coming year and look forward to your participation, hopefully in greater numbers and depending upon the state of global politics and economy from a wider geographical background and at a higher level. Further details regarding the call for papers and schedule 
for next year will be made available in due course on the Internet at SPIE (www.spie.org) as well as on my home page (http://belur.no-ip.com).

Continuing our tradition, the size (and variations thereof) of these proceedings in terms of the number of papers offered under this series over the years is graphically illustrated below in Figure 1 to provide us with an introspective look at our performance over the years. The presentations this year is slightly below last year.

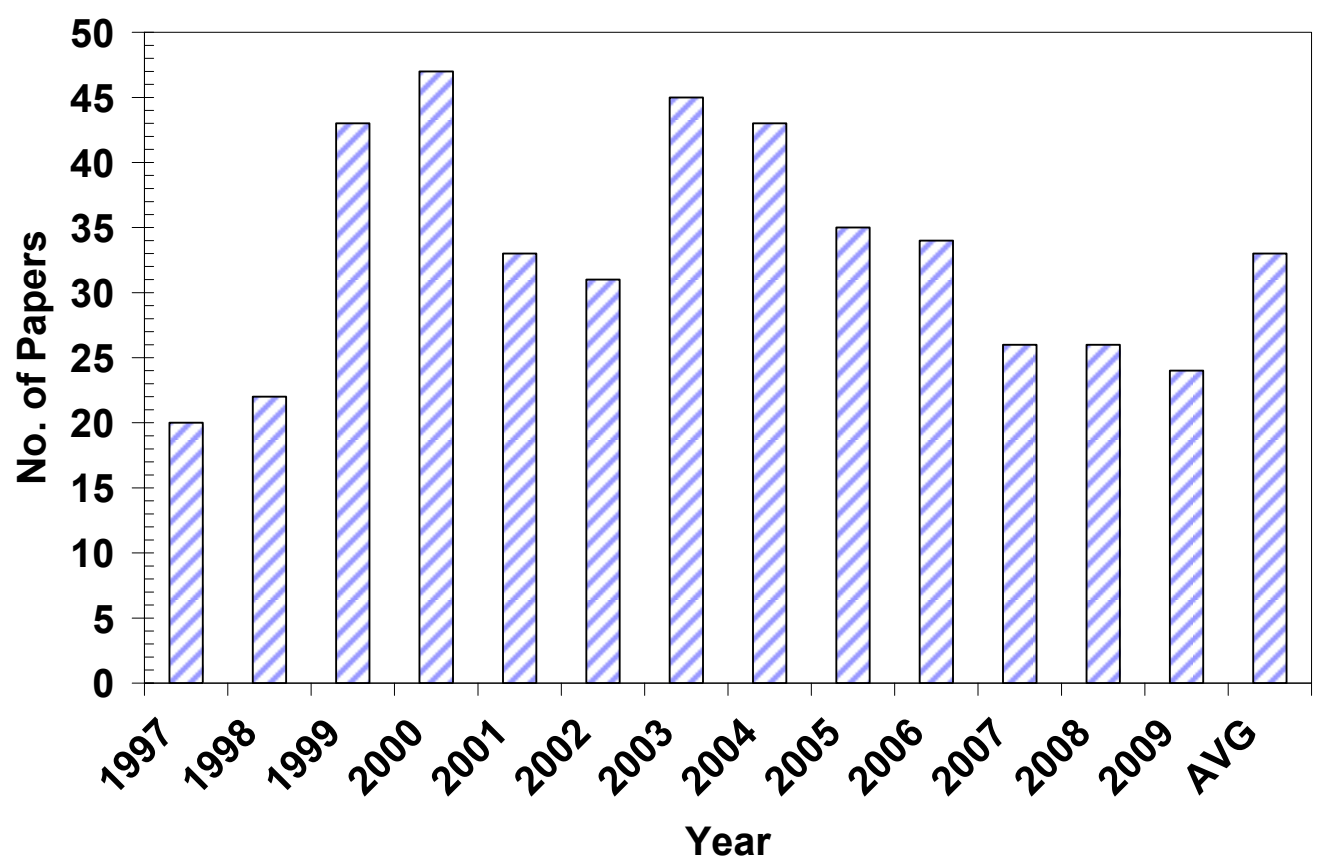

Figure 1. Number of papers published over the years in this series

Given the negative trend, It is critical that all of us who are interested in the continued success of this annual event to maximize our efforts for next year to ensure continued viability of the conference in the future. Towards this end, we welcome from the conference participants and the readership of this proceedings on ways to rejuvenate the growth of this conference and broaden its appeal in the coming years. Those interested in active participation, perhaps in terms of joining the program committee and/or develop special sessions for the next year should contact me at fusion-consultant@ieee.org as soon as possible (preferably by April 30, 2009).

In closing, I would like to take this opportunity to acknowledge the authors for choosing this avenue for publication of their contributions. My thanks are also due to the members of our program committee and the session chairs for their 
continued support. We would be amiss if we fail to recognize the efforts of the SPIE staff in making this possible in a timely fashion.

\section{कायेन वाच्रा मनसेन्द्रियैर्वा बुध्यात्मनावा प्रकृते स्वभावात करोमि यद्यत सकलं परस्मे ध्रीमन्नारायणायेति समर्पयामि}

"kaayena vaachaa manasendriyairvaa budhyaatmanaavaa prakR^ite svabhaavaat karomi yadyat sakalaM parasmai shriiman naaraayaNaayeti samarpayaami"
Be it with my body, or with my mind With words, or organs of any kind, With my intellect, or with my soul, Or by force of Nature pushing me to my goal, Whatever it is, with all these I do,

Oh! Supreme Lord! I surrender to you.

Wishing all of you a safe return journey

Belur V. Dasarathy, Ph. D, FIEEE Chairman http://belur.no-ip.com fusion-consultant@ieee.org 
Downloaded From: https://www.spiedigitallibrary.org/conference-proceedings-of-spie on 26 Apr 2023

Terms of Use: https://www.spiedigitallibrary.org/terms-of-use 